[8] Myroshnyk, Yu. A., Kosakivska, H. S., Dotsenko, V. F., Havrysh, A. V. (2013). Pat. No. 83989 UA. Kompozytsiya dlia vyhotovlennia biskvitnoho napivfabrykatu. u201303613; declareted: 22.03.2013; published: 10.10.2013, Bul. No. 19.

[9] Fillipova, E. V., Krasina, I. B., Navitskaya, D. P. (2012). Uluchshenie strukturnyh harakteristik i obogashchenie poroshkom topinambura vafel'nyh listov. Innovatsionnye napravleniya v pishchevyh tehnologiyah: Materialy 5 Mezhdunarodnoy nauchno-prakticheskoy konferentsii. Pyatigorsk, 332-335.

[10] Kozarenko, T. D. (1975). Ionoobmennaya hromatografiya aminokislot. Novosibirsk: «Nauka», 134.

[11] Obolkina, V. I., Sivniy, I. I. (2011). Ryabina v konditerskih izdeliyah. Produkty\&Ingredienty, 11, 30-31.

[12] Yakovleva, T. P., Filimonova, E. Yu. (2011). Pishchevaya i biologicheskaya tsennost' plodov oblepihi. Pishchevaya promyshlennost', 2, 11-13.

[13] Skurihin, M. M., Tutel'yan, A. A. (2007). Tablitsy himicheskogo sostavai kaloriynosti rossiyskih produktov pitaniya. Moscow: DeLi print, 610 .

\title{
STUDY OF THE INFLUENCE OF MEALS OF WHEAT AND OAT GERMS AND WILD ROSE FRUITS ON THE FERMENTING MICROFLORA ACTIVITY OF RYE-WHEAT DOUGH
}

\author{
Svitlan Oliinyk ${ }^{1}$ \\ svitlana.oliinyk@gmail.com \\ Olga Samokhvalova ${ }^{1}$ \\ sam55ov@gmail.com \\ Nadegda Lapitskaya ${ }^{1}$ \\ nadegda.lapitskaja@gmail.com \\ Zinoviya Kucheruk ${ }^{1}$ \\ kzinoviya2703@gmail.com \\ ${ }^{1}$ Department of Bakery, Confectionary, Pasta and Food Concentrates Technology \\ Kharkiv State University of Food Technology and Trade \\ 333 Klochkivska str., Kharkiv, Ukraine, 61051
}

\footnotetext{
Abstract

The aim of the research was to study an influence of meals of wheat germs (WGM) and oat germs (OGM) in amount $10 \ldots 20 \%$, and also ones of wild rose fruits (WRFM) in amount $2 \ldots 6 \%$ of the total mass of flour on the fermenting microflora of rye-wheat dough; and also to establish an influence of the experimental supplements on main microbiological processes in it.

It has been established, that adding experimental meals favors the activation of bakery yeast. At introducing WGM, OGM and WRFM, its lifting force grows by 16.0-54.0, 6.0-18.0, 10.0-44.0 \% respectively, and zymase and maltase activity - by 16.0-53.3, 6.0-17.7 and 11.1-44.0\% and 18.8-55.0, 6.331 .3 and 7.5-25.0\% respectively. It has been established, that there also takes place the activity increase of lactate bacteria in rye-wheat dough with adding meals of wheat, oat germs and wild rose fruits. It is possible at the expanse of adding an additional nutritive medium with the supplements.

Such action of enriching raw materials on the microflora favors intensification of alcoholic and lactate fermentation that is established by data of acid accumulation and gas formation in rye-wheat dough. The counted indices at introducing WGM, OGM, WRFM increase by 39.0, 27.8, 33.9 \% and 18.2, 13.6, $16.7 \%$ respectively.

Keywords: rye-wheat dough, wheat germ meal, oat germ meal, wild rose fruit meal, lactate bacteria, lifting force, fermenting activity, microbiological processes.
} 


\section{Introduction}

An important problem, faced by mankind last years, is the abrupt spread of "civilization diseases" with an alimentary character. In this connection an urgent direction of the food industry is the development of technologies of healthy products with an increased content of functional-physiological elements, based on fruit-berry, vegetable grain raw materials and so on [1-4]. In many European countries, including Ukraine, bread of the mixture of rye and wheat flour is very popular that makes it a promising object for enriching with essential substances.

For increasing the food and biological value of bakery products, there are successfully used non-traditional types of vegetable raw materials with essential contents of biologically active substances. Introduction of such raw materials to dough recipes may influence the vital activity of its fermenting microflora, namely lactate bacteria and yeast that play an important role in the formation of the rye-wheat dough quality. Products of lactate fermentation that are mainly organic acids favor the improvement of dough rheological characteristics and formation of a taste and smell of bread. The dough fluffiness, porosity status and volume of ready products are mainly conditioned by the intensity of alcoholic fermentation, which agent is yeast [5].

At adding processing products of raw materials, easily assimilated sugars and also mineral and other biologically active substances are additionally introduced in dough. It results in improving technological characteristics of yeast, favors the activation of lactate bacteria. Thus, it has been established, that introduction of potato and beetroot paste in dough favors intensification of acid accumulation in rye-wheat dough and increase of the yeast lifting force [6]. There are also known data about a positive influence of potato powder [7], carrot juice [8], honeysuckle puree [9], powder of pumpkin pressed skins [10] on the activity of bakery yeast that results in intensification of alcoholic fermentation in wheat and rye-wheat dough.

Introduction of chicory root powder in small dosages (less $1 \%$ ) favors the increase of zymase and maltase activity of yeast, and the increase of its dosage results in inhibition of yeast cells at the expanse of coumarin that inhibits the development of yeast cells at high concentrations [11].

There is information about a positive influence of pea-anisic decoction on reproduction of yeast cells and lactate bacteria in dough in wheat leaven. Such effect is observed at the expanse of introducing vitamins and mineral substances of an enriching raw material that is an additional nutritive medium for the fermenting microflora [12]. But adding cultures, containing mucus, for example, comminuted golden flax seeds, dry or wet, results in the intensity decrease of gas formation in dough. It is connected with the decrease of yeast microflora activity at the expanse of its covering by flax mucus. It is offered to solve this problem by preparing bread on oat leaven [13].

From the scientific and practical point of view, meals of wheat and oat germs - secondary products at making germ and oat oils - are interesting for enriching rye-wheat bread. The experience of using these supplements in the technology of wheat sorts of bread testifies that their introduction in amount $10-20 \%$ of the flour mass favors intensification of gas formation and acid accumulation in wheat dough [14-16]. Thus, at adding wheat germ meal, an amount of $\mathrm{CO}_{2}$, emitted at dough fermentation increases by $7.5-15.7 \%$, and titrated acidity - by $26.0-50.0 \%$ respectively [14]. At using oat germ meal, these indices also increase by $7.1-16.5 \%$ and $13.3-40.0 \%$, comparing with a sample of wheat dough without supplements $[15,16]$. The authors explain it by the possible activation of lactate bacteria in wheat dough at the expanse of introducing additional amino acids, mineral and other biologically active substances together with meals. But in these works the influence of oat and wheat germ meals on the status and activity of the fermenting microflora is insufficiently studied.

The expedience of using wild rose fruits and their processing products for activating the fermenting microfora activity and intensifying dough maturation processes is also proved in bakery [17-19]. It is possible because of the essential content of vitamins in them that are mainly presented by ascorbic acid, and mineral substances. Carbohydrates of such raw materials mainly consist of mono- and disaccharides that are also positive for the microflora activity. Work [20] proves that the use of syrup or juice of wild rose fruits as a nutritive medium has a stimulating influence on the yeast activity. According to the authors' data, adding vitamins that are growth factors for yeast cells with syrup or juice of wild rose fruits favors intensification of yeast cells reproduction. The intensity of $\mathrm{CO}_{2}$ synthesis in experimental samples increased in 1.6 (with syrup) and 2.1 (with juice) times, comparing with the control. 
As a research result of the influence of water and serum extracts of wild rose fruits in amount 30 and $15 \%$ of the liquid fraction mass in wheat dough, it has been established, that their introduction favors the improvement of conditions for anabolic and catabolic processes in yeast cells. There has been established the positive influence of extracts on technological properties and generative functions of yeast. Such changes result in intensification of biochemical and microbiological processes in wheat dough [17].

It is also known, that it is effective for getting high-quality wheat bread to use wild rose fruit powder in amount $5 \%$ of the four mass [18] or wild rose fruit and ashberry powders together in amount $1-3 \%$ of the flour mass [19]. These supplements favor intensification of maturation processes and getting products with high quality indices. But the influence of powders on technological characteristics of yeast and lactate bacteria is not established in these studies.

A promising raw material for the bakery branch is wild rose fruit meal - secondary product in the technology of the correspondent oil. It includes the essential amount of dietary fiber (near $50 \%$ ), and also mineral substances and vitamins, especially ascorbic acid (46.6 mg/100 g) [21]. Scientific information about using wild rose fruit meal for influencing the status of the fermenting microflora of rye-wheat dough has not been found.

The aim of the research was to study an influence of meals of wheat and oat germs and ones of wild rose fruits on the fermenting microflora of rye-wheat dough.

The following tasks were set for attaining this aim:

- to study an influence of meals of wheat germs (WGM), oat germs (OGM), wild rose fruits (WRFM) on technological characteristics of bakery yeast and activity of lactate bacteria;

- to study an influence of the experimental meals on microbiological maturation processes in rye-wheat dough.

\section{Materials and methods}

Peeled rye flour, wheat flour of the first sort, pressed bakery yeast, dry rye leaven, kitchen salt, wheat germ meal, oat germ meal, wild rose fruit germ meal were used in the studies. The mass share of moisture of the experimental meals was $12.4,11.4$ and $7.1 \%$ respectively. WGM acidity was 6.0 degrees, OGM - 5.9 degrees, WRFM - 53.0 degrees [14-16, 21].

The chemical composition of rye, wheat flour and experimental meals is presented in Table 1.

Table 1

The content of nutritive, ballast and biologically active substances in the experimental meals $[5,15,16]$

\begin{tabular}{|c|c|c|c|c|c|}
\hline \multirow{2}{*}{$\begin{array}{l}\text { Name of nutritive and } \\
\text { biologically active substances }\end{array}$} & \multicolumn{5}{|c|}{ Mass share of substance in the raw material } \\
\hline & Peeled rye four & $\begin{array}{c}\text { Wheat flour of } \\
1 \text { sort }\end{array}$ & $\begin{array}{c}\text { Wheat germ } \\
\text { meal }\end{array}$ & Oat germ meal & Wild rose meal \\
\hline Protein, \% & 8.9 & 10.6 & 45.0 & 23.0 & 5.7 \\
\hline Fat, \% & 1.7 & 1.3 & & traces & \\
\hline Carbohydrates, \%: & 73.2 & 72.0 & 44.8 & 58.4 & 15.5 \\
\hline Including mono-, disaccharides & 4.5 & 1.8 & 18.0 & 5.1 & 15.9 \\
\hline starch & 59.3 & 69.1 & traces & 30.0 & 0.4 \\
\hline Non-starch polysaccharides, $\%$ & 13.2 & 4.0 & 26.0 & 23.3 & 43.4 \\
\hline \multicolumn{6}{|l|}{ Mineral substances $(\mathrm{mg} / 100 \mathrm{~g})$ : } \\
\hline Sodium & 17.0 & 12.0 & 7.3 & 24.8 & 11.7 \\
\hline Potassium & 350.0 & 176.0 & 2190.0 & 812.50 & 3543.0 \\
\hline Calcium & 34.0 & 24.0 & 115.0 & 57.0 & 336.8 \\
\hline Magnesium & 60.0 & 44.0 & 220.0 & 280.0 & 813.3 \\
\hline Cooper & - & - & 1.8 & 1.5 & 3.9 \\
\hline Iron & 3.5 & 2.1 & 7.1 & 15.0 & 4.40 \\
\hline Zinc & - & - & 21.9 & 10.5 & 3.5 \\
\hline Manganese & - & - & 36.0 & 15.0 & 15.0 \\
\hline
\end{tabular}


The lifting force of yeast was determined by the arbitral method according to SSU 4812:2007, measuring time that dough lifts by $70 \mathrm{~mm}$ in.

The zymase and maltase yeast activity was determined, using a device with a manometer and fixed corks. $0.5 \mathrm{~g}$ of yeast and $10 \mathrm{~cm}^{3}$ of water with temperature $35{ }^{\circ} \mathrm{C}$, were placed in it and accurately mixed. Yeast suspension was added with $10 \mathrm{~cm}^{3}$ of $10 \%$ solution of one of sugars (glucose or maltose). The device was closed, a tap was open for equating an internal pressure with the atmospheric one, and the device was placed in a thermostat at temperature $30{ }^{\circ} \mathrm{C}$. In 5 min the tap was closed, and a liquid level in a graded tube was fixed. The device was left in the thermostat. The determination was considered as finished, when a saline solution in the tube rose by $10 \mathrm{~cm}^{3}$ [22].

For determining the activity of lactate bacteria, there were taken $20 \mathrm{~g}$ of rye-wheat dough and $40 \mathrm{~cm}^{3}$ of distilled water with temperature $39 \pm 1{ }^{\circ} \mathrm{C}$, rubbed in a mortar to the homogenous consistence and taken in two test-tubes, $10 \mathrm{~cm}^{3}$ of the obtained suspension in each one. One of testtubes was added with $1 \mathrm{~cm}^{3} 0.05 \%$ of the blue methylene water solution, and the other one was a control for comparing a color. The tubes were covered by rubber corks, shaken and placed in the thermostat with temperature $40{ }^{\circ} \mathrm{C}$. The time, in which blue methylene became colorless in them, was fixed [23].

The gas-forming capacity of rye-wheat dough was determined by the amount of $\mathrm{CO}_{2}$, emitted at maturation [23]. The titrated acidity - by the conventional method, presented in [23].

Fisher-Student method was used for processing the experimental data at reliability level 0.95. The research results were calculated as a mean of no less five iterations.

\section{Experiments}

One of main normative characteristics of bakery yeast that allows to judge about the lifting speed of dough, prepared of it, is a lifting force index. But this method allows to estimate only the activity of the zymase complex of yeast, whereas the intensity and duration of dough fermentation are determined mainly by the speed maltose supply to a cell and disintegration. In this connection the influence of the experimental meals on the bakery yeast activity was determined by the complex of parameters, namely by the lifting force and indices of the activity of zymase complex enzymes and maltose activity.

There was studied the activity of lactate bacteria at presence of meals of wheat and oat germs and wild rose fruits by preparing rye-wheat dough with them. The analogous index in dough without supplements was determined for comparing.

For establishing the influence of the fermenting microflora of rye-wheat dough with the experimental meals on processes that take place at maturation, the gas-forming capacity of dough was studied. The influence of the supplements on the acid accumulation intensity in rye-wheat dough was also studied.

After conducting these studies, a control sample was prepared of the mixture of peeled rye and wheat flour of 1 sort in ratio 1:1, $2.5 \%$ of dry rye leaven, $2 \%$ of bakery pressed yeast, $1.5 \%$ of kitchen salt. Maturation was conducted during $90 \mathrm{~min}$ at temperature $30 \pm 2{ }^{\circ} \mathrm{C}$.

The experimental sample were added with WGM or OGM in amount $10-20 \%$ of the total four mass, and WRFM - in amount 2-6 \% of the total flour mass. Experimental intervals of dosages of WGM and OGM were chosen, based on the research results as to their use in the wheat bread technology [14-16], and wild rose fruit meal amount - based on the data, presented in work [21].

It is demonstrated, that adding wheat and oat germ meals and also wild rose fruit meal to model systems of yeast and rye-wheat dough favors the fermenting microflora activity increase (Tables 2, 3, Fig. 1).

According to the data, presented in Table 2, introduction of WGM, OGM and WRFM favors the increase of the lifting force index of bakery yeast that testifies to its activity increase. At that the most influence on this index is made by wheat germ and wild rose fruit meals - at their addition it decreases by $16.0-540$ and $10.0-44.0 \%$. At adding oat germ meal the lifting force of yeast rises by $6.0-18.0 \%$.

The positive influence of meals of wheat and oat germs and wild rose fruits on the fermenting activity of bakery yeast was proved also at determining its enzymic activity (Table $\mathbf{3}$ ). 
Table 2

The influence of meals of wheat and oat germs and wild rose fruits on the lifting force of bakery yeast

\begin{tabular}{|c|c|c|c|c|c|c|c|c|c|c|}
\hline \multirow{4}{*}{$\begin{array}{c}\text { Quality } \\
\text { parameters of } \\
\text { yeast }\end{array}$} & \multicolumn{10}{|c|}{ Experimental samples } \\
\hline & \multirow{3}{*}{$\begin{array}{l}\text { Without supplements } \\
\text { (control) }\end{array}$} & \multicolumn{9}{|c|}{ With the experimental meals, $\%$ of the total flour mass } \\
\hline & & \multicolumn{3}{|c|}{ WGM } & \multicolumn{3}{|c|}{ OGM } & \multicolumn{3}{|c|}{ WRFM } \\
\hline & & 10 & 15 & 20 & 10 & 15 & 20 & 2 & 4 & 6 \\
\hline Lifting force, $\min$ & 50 & 42 & 31 & 23 & 47 & 44 & 41 & 45 & 37 & 28 \\
\hline
\end{tabular}

Table 3

The influence of meals of wheat and oat germs and wild rose fruits on the enzymic activity of bakery yeast

\begin{tabular}{|c|c|c|c|c|c|c|c|c|c|c|}
\hline \multirow{4}{*}{$\begin{array}{c}\text { Quality } \\
\text { parameters of } \\
\text { yeast }\end{array}$} & \multicolumn{10}{|c|}{ Experimental samples } \\
\hline & \multirow{3}{*}{$\begin{array}{l}\text { Without supplements } \\
\text { (control) }\end{array}$} & \multicolumn{9}{|c|}{ With the experimental meals, $\%$ of the total flour mass } \\
\hline & & \multicolumn{3}{|c|}{ WGM } & \multicolumn{3}{|c|}{ OGM } & \multicolumn{3}{|c|}{ WRFM } \\
\hline & & 10 & 15 & 20 & 10 & 15 & 20 & 2 & 4 & 6 \\
\hline $\begin{array}{l}\text { Zymase activity, } \\
\text { min }\end{array}$ & 45.0 & 37.8 & 27.9 & 21.0 & 42.3 & 39.6 & 37.0 & 40.0 & 33.3 & 25.2 \\
\hline $\begin{array}{l}\text { Maltase activity, } \\
\min \end{array}$ & 80.0 & 65.0 & 50.0 & 36.0 & 75.0 & 67.0 & 55.0 & 74.0 & 68.0 & 60.0 \\
\hline
\end{tabular}

It is testified by the decrease of the yeast zymase activity index at adding WGM - by $16.0-53.3 \%$, at adding OGM - by $6.0-17.7 \%$ and at using WRFM - by $11.1-44.0 \%$. The maltase activity at introducing WGM and OGM increases by $16.0-53.3$ and $6.0-17.7 \%$, and at adding WRFM - by $11.1-44.0 \%$.

It has been also established, that the experimental meals favor the activity increase of lactate bacteria (Fig. 1).

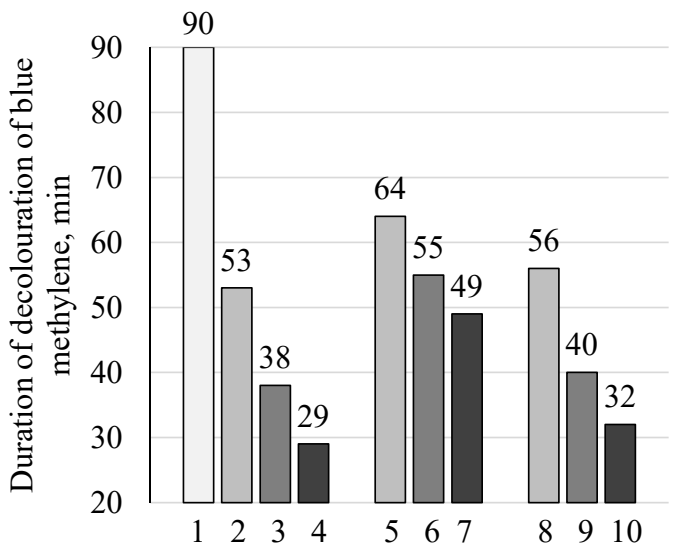

Fig. 1. Activity of lactate bacteria in dough: 1 - without addition (control); without addition:

$2-10 \%$ WGM, 3 - $15 \%$ WGM, 4 - $20 \%$ WGM, 5 - $10 \%$ OGM, 6 - $15 \%$ OGM, $7-20 \%$ OGM, 8 - $2 \%$ WRFM, $9-4 \%$ WRFM, $10-6 \%$ WRFM

Moreover like in the studies of the meals' influence on the yeast activity, the positive influence of WGM and WRFM is more expressed, comparing цшер oat germ meal. Thus, it is established, that at adding WGM, WRFM and OGM in rye-wheat dough in the experimental intervals of dosages, the decolouration duration of blue methylene shortens by $41.1-67.8 \%$, $37.8-64.4 \%$ and $28.9-45.5 \%$ respectively, comparing with this index in a sample without supplements.

So, adding $10 \ldots 20 \%$ of wheat and oat germ meals and $2 \ldots 6 \%$ of wild rose fruit meal favors the activity increase of bakery yeast and lactate bacteria. It was also proved by the data about gas 
formation and acid accumulation in rye-wheat dough at their adding in amount $15 \%$ for WGM and OGM and $4 \%$ - for WRFM of the flour mass (Fig. 2, 3).

Thus, it is established (Fig. 2) that introduction of the experimental supplements results in intensification of fermentation in dough that is testified by the higher amount of emitted $\mathrm{CO}_{2}$ at all fermentation stages. At the end of maturation its amount in dough samples with meals of wheat and oat germs and wild rose fruits was by $39.0 \%, 27.8 \%$ and $33.9 \%$ higher than in the control sample.

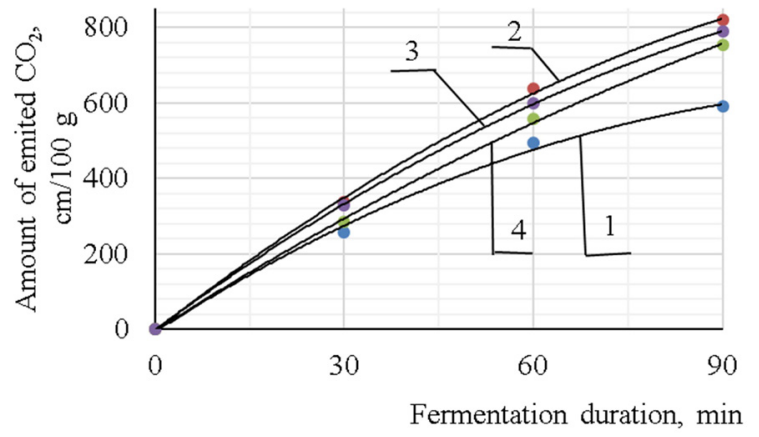

Fig. 2. Influence of the supplements on the amount of emitted $\mathrm{CO}_{2}$ in rye-wheat dough: 1 - control (without supplements); with adding: $2-15 \%$ of WGM, $3-15 \%$ of OGM, $4-4 \%$ of WRFM

The analysis of the data, presented on Fig. 3, testifies that adding the experimental meals results in both the increase of initial titrated acidity of rye-wheat dough and its more intense change at maturation.

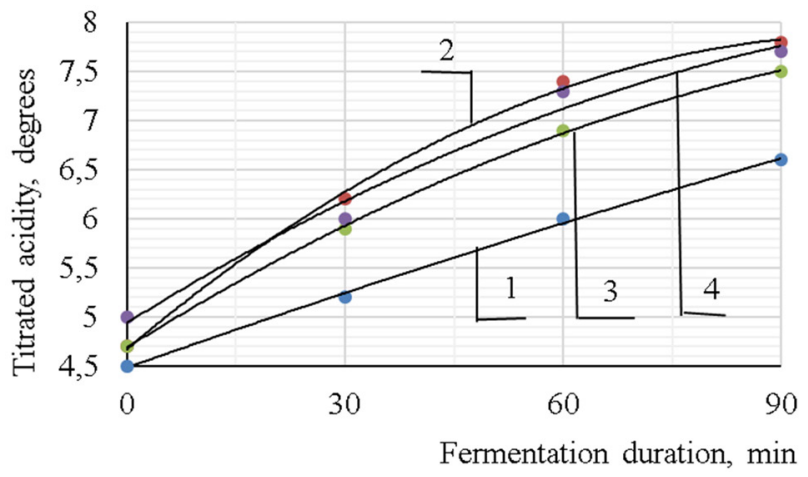

Fig. 3. Influence of the supplements on the titrated acidity change in rye-wheat dough: 1 - control (without supplements); with adding: $2-15 \%$ of WGM, $3-15 \%$ of OGM,

$$
4-4 \% \text { of WRFM }
$$

Thus, at the end of the experiment the value of this parameter of dough at adding WGM, OGM and WRFM was higher than the one of the control sample by $18.2 \%, 13.6 \%$ and $16.7 \%$ respectively.

\section{Results}

The results of the complex of conducted studies allowed to establish the positive influence of meals of wheat, oat germs and wild rose fruits in the experimental interval of dosages on the activity of bakery yeast and one of lactate bacteria.

The essential improvement of its lifting force (Table 2) and fermenting activity (Table 3) indices at presence of supplements is, probably, conditioned by the additional introduction of easily accessible sugars, mineral substances, proteins and other components, nutritive for yeast cells, contained more in the experimental meals than in wheat and rye flour, together with meals (Table 1). The best indices of lifting force, maltase and zymase activity are observed at introducing 
wheat germ meal that may be connected with the higher content of mono- and disaccharides in this supplement, comparing with the other experimental meals.

In samples with adding wild rose fruit meal with high titrated acidity (53.0 degrees) the activation effect may be conditioned also by decreasing dough $\mathrm{pH}$ to the values, favorable for the yeast vital activity. These causes may also explain the activity increase of lactate bacteria in ryewheat dough with the meals.

The activity increase of the dough fermenting microflora at presence of the meals in the experimental dosages became a precondition for intensifying microbiological processes in dough, especially alcoholic and lactate fermentation, resulting in acceleration of gas formation (Fig. 2) and acid accumulation (Fig. 3).

The acceleration of microbiological processes influences the acidity of baked products, their porosity and specific volume and may be a precondition for shortening the maturation duration of dough semi-products. Such problems need special studying. So, further studies will be directed on determining the influence of meals of wheat, oat germs and wild rose fruits on structural-mechanical properties of rye-wheat dough and quality of ready products.

\section{Conclusions}

It has been proved, that at presence of wheat and oat germ meals in amount $10 \ldots 20 \%$ of the flour mass and ones of wild rose fruits in amount $2 . .6 \%$ of the flour mass the bakery yeast activity increases. At introducing WGM and OGM, its lifting force grows by $16.0-54.0$ and $6.0-18.0 \%$ respectively, and at adding WRFM - by $10.0-44.0 \%$, that is caused by its zymase and maltase activity improvement. The activity of lactate bacteria also increases at adding WGM and OGM by $41.1-67.8 \%$ and $28.9-45.5 \%$ respectively and at presence of WRFM - by $37.8-64.4 \%$.

2. It has been established, that adding wheat and oat germ meals in amount $10 \ldots 20 \%$ and ones of wild rose fruits in amount $2 . .6 \%$ of the total flour mass favors intensification of maturation processes in rye-wheat dough. It is testified by its titrated acidity indices, higher than ones of the control samples by $18.2 \%, 13.6 \%$ and $16.7 \%$, and also by ones of emitted carbon dioxide, higher by $39.0,27.8,33.9 \%$ respectively.

\section{References}

[1] Kaprelyants, L., Yegorova, A., Trufkati, L., Pozhitkova, L. (2019). Functional foods: prospects in Ukraine. Food Science and Technology, 13 (2). doi: https://doi.org/10.15673/fst.v13i2.1382

[2] Daliri, E. B.-M., Lee, B. H. (2015). Current Trends and Future Perspectives on Functional Foods and Nutraceuticals. Microbiology Monographs, 221-244. doi: https://doi.org/10.1007/978-3-319-23177-8_10

[3] Pavlyuk, R., Pogarskaya, V., Radchenko, L., Yurieva, O., Gasanova, A., Abramova, A., Kolomiets, T. (2015). The development of technology of nanoextracts and nanopowders from herbal spices for healthful products. Eastern-European Journal of Enterprise Technologies, 3 (10 (75)), 54-59. doi: https://doi.org/10.15587/1729-4061.2015.43323

[4] Zagorulko, A., Zahorulko, A., Kasabova, K., Chervonyi, V., Omelchenko, O., Sabadash, S. et. al. (2018). Universal multifunctional device for heat and mass exchange processes during organic raw material processing. Eastern-European Journal of Enterprise Technologies, 6 (1 (96)), 47-54. doi: https://doi.org/10.15587/1729-4061.2018.148443

[5] Drobot, V. I. (2019). Dovidnyk z tekhnolohiyi khlibopekarskoho vyrobnytstva. Kyiv, 580.

[6] Berezina, N. A. (2012). Rasshirenie assortimenta i povyshenie kachestva rzhano-pshenichnyh hlebobulochnyh izdeliy s saharosoderzhashchimi dobavkami. Orel: FGBOU VPO «Gosuniversitet - UNPK», 232.

[7] Ildirova, S. K., Simakova, O. O., Popova, S. Y. (2014). Using of dry potato additives in the production technologies of yeast semi-finished products. Visnyk Donetskoho natsionalnoho universytetu ekonomiky i torhivli im. Mykhaila Tuhan-Baranovskoho. Ser.: Tekhnichni nauky, 1, 54-62.

[8] Edygova, S. N., Khatko, Z. N., Teknedzhan, A. A. (2019). The influence of carrot juice on the quality indicators of wheat bread from the first grade flour. Novye Tehnologii (MAJKOP), 1 (47), 47-56. doi: http://doi.org/10.24411/2072-0920-2019-10105

[9] Zaharova, A. S., Kozubaeva, L. A., Kolesnichenko, M. N. (2014). Kachestvo zhidkih rzhanyh zakvasok s zavarkoy pri ispol'zovanii pyure zhimolosti. Teoreticheskie osnovy i innovatsionnye modeli pererabotki produktsii sel'skogo hohyaystva i proizvodstva ekologicheski chistyh produktov v regione, 1.

[10] Atamuratova, T. I., Mohnacheva, A. I., Vasil'ev, M. G., Mahmadaliev, B. D. (1992). Sovershenstvovanie protsessa proizvodstva rzhanyh sortov hleba. Izvestiya vuzov. Pishchevaya tehnologiya, 5-6, 44-45. 
[11] Savchenko, O., Sizaya, O., Zinchenko, Y., Derkach, T., Mykhailova, M. (2016). The impact of chicory, coffee and lemon juice on the enzymatic activity of yeast and the quality of wheat bread. Tekhnichni nauky ta tekhnolohiyi, 1 (3), 228-233.

[12] Lebedenko, T., Kozhevnikova, V., Kotuzaki, O., Novichkova, T. (2019). Determining the efficiency of spontaneous sourdough for stabilizing the quality of bread products in bakeries and catering enterprises. Eastern-European Journal of Enterprise Technologies, 4 (11 (100)), 22-35. doi: https://doi.org/10.15587/1729-4061.2019.174289

[13] Bondarenko, Y., Mykhonik, L., Bilyk, O., Kochubei-Lytvynenko, O., Andronovich, G., Hetman, I. (2019). The use of golden flax seeds and oats sourbread in the production of wheat bread. Eastern-European Journal of Enterprise Technologies, 4 (11 (100)), 46-55. doi: https://doi.org/10.15587/1729-4061.2019.174643

[14] Oliynyk, S. H., Lysiuk, H. M., Kravchenko, O. I., Samokhvalova, O. V. (2014). Tekhnolohiyi khlibobulochnykh vyrobiv iz produktamy pererobky zarodkiv pshenytsi. Kharkiv: KhDUKhT, 108.

[15] Oliynyk, S. H., Stepankova, H. V., Kravchenko, O. I. (2014). Doslidzhennia perebihu protsesiv dozrivannia pshenychnoho tista z vykorystanniam produktiv pererobky vivsa ta kukurudzy. Naukovi pratsi ONAKhT, 46 (1), 137-142.

[16] Oliynyk, S. H., Stepankova, H. V., Kravchenko, O. I., Kasabova, K. R. (2016). Khlib pshenychnyi pidvyshchenoi kharchovoi tsinnosti z produktamy pererobky zarodkiv zernovykh kultur. Khlibnyi ta kondyterskyi biznes, 9, 28-30.

[17] Lebedenko, T. S., Kozhevnikova, O. V., Sokolova, N. Yu. (2015). Udoskonalennia protsesu aktyvatsiyi drizhdzhiv shliakhom vykorystannia fitodobavok. Kharchova nauka i tekhnolohiya, 2, 25-34.

[18] Perfilova, O. V. (2010). New kind of bread with dog-rose. Dostizheniya nauki i tehniki APK, 08, 77-78.

[19] Aparsheva, V. V. (2011). Powdery product from hips and the mountainash in technology of bakery products. Izvestiya vysshih uchebnyh zavedeniy. Pishchevaya tehnologiya, 5-6, 102-103.

[20] Kuznetsova, T. A., Ivanchenko, O. B., Kalinkin, N. S. (2017). Influence of the rose hips components on the morpho-physiological state of yeast cells. International Research Journal, 08 (62), 16-20. doi: http://doi.org/10.23670/IRJ.2017.62.065

[21] Oliinyk, S. H., Samokhvalova, O. V., Lapytska, N. V. (2019). Doslidzhennia vplyvu shrotu plodiv shypshyny na tekhnolohichni vlastyvosti zhytnoho ta pshenychnoho boroshna. Innovatsiyni tekhnolohiyi u khlibopekarskomu vyrobnytstvi: Mater. dop. Mizhnar. spets. nauk.-prakt. konf. Kyiv: NUKhT, 32-35.

[22] Kapreliants, L. V., Pylypenko, L. M., Yehorova, A. V. et. al. (2016). Mikrobiolohiya kharchovykh vyrobnytstv. Kherson: Vydavets FOP Hrin D.S., 478.

[23] Drobot, V. I. (2015). Tekhnokhimichnyi kontrol syrovyny ta khlibobulochnykh i makaronnykh vyrobiv. Kyiv: KondorVydavnytstvo, 972. 